\title{
Osmanlı Dönemi Bir Sanayi İşletmesi Olarak Değirmenler: Tosya Nahiyesi Örneği (1578/1579)
}

\author{
İlker YİĞíT" - Ziya Çağrı YAZGAN"
}

\begin{abstract}
ÖZ
Değirmen, özellikle Endüstri Devrimi öncesi toplumlarda tarımsal faaliyetlerin tamamlayıcısı ve birer sanayi işletmesi olarak önemli bir yere sahip olmuştur. Bu çalışmada da Osmanlı Devleti'nde sanayi işletmeleri olarak faaliyet gören değirmenler tarihi coğrafya perspektifiyle ele alınarak, XVI. yüzyıl Tosya nahiyesindeki dağılışı, yoğunluğu, işletim şekilleri, işletim süreleri ve harap olma durumları ortaya konmaya çalışılmıştır. Çalışma kapsamında 1579 Tarihli Çankırı Mufassal Tahrir Defteri isimli eserden sahaya ait olduğu tespit edilen değirmen ve yerleşme verileri tablolara aktarılmıştır. Söz konusu yerleşme ve değirmenlerin lokalizasyonu 1/200.000 ölçekli topografya haritasından yararlanılarak yapılmıştır. Ayrıca Tosya şehri ve köylerinde arazi araştırması gerçekleştirilmiş olup yerel halkla yapılan mülakatlar ile değirmenlerin işletim şekillerine, sürelerine ve yok olmalarına dair önemli bilgiler elde edilmiştir. Daha sonra arşiv kaynağı ve arazi araştırmasından elde edilen bilgiler literatür de göz önünde bulundurularak değerlendirilmiştir. Bu bilgiler 1şı̆̆ında, 1578/1579 tarihinde Tosya nahiyesinde 49 değirmenin mevcudiyeti tespit edilmiştir. İlgili tarihte Tahrir defterinde yer alan değirmenlerin 40'1 aktif olarak işletilirken 9'unun harap olduğu görülmektedir. Ayrıca yapılan harita üzerinde değirmenlerin dağılışına bakıldığında yerleşmelere yakın yerlerde bulunan akarsu boylarında ve yükselti bakımından elverişli olan sahalarda değirmenlerin yoğunlaştığı anlaşılmaktadır.
\end{abstract}

Anahtar Kelimeler: Tarihi coğrafya, Osmanlı sanayi, değirmen, Tahrir defteri, Tosya.

Doç. Dr. Burdur Mehmet Akif Ersoy Üniversitesi, Fen Edebiyat Fakültesi, Coğrafya Bölümü/ Burdur/Türkiye

E-posta: iyigithg@gmail.com, ORCID: 0000-0002-1473-3438,DOI: 10.32704/erdem.2021.81.175

Doktora Öğrencisi, Burdur Mehmet Akif Ersoy Üniversitesi, Sosyal Bilimler Enstitüsü, Coğrafya Anabilim Dalı/Burdur/Türkiye

E-posta: ziyayazgan0606@gmail.com, ORCID: 0000-0002-9331-5428.

Makale Gönderim Tarihi: 30.09.2020 * Makale Kabul Tarihi: 29.11.2021 * (Araştırma Mk.) 


\title{
Mills As A Industrial Enterprise Of the Ottoman Period: The Example Of Tosya Nahiye (1578/1579)
}

\begin{abstract}
The mill has had an important place as an industrial enterprise and complementary to agricultural activities in societies before the Industrial Revolution. In this study, the mills operating as industrial enterprises in the Ottoman Empire were handled with a historical geography perspective, and their distribution in the 16th century Tosya sub-district, their distribution, density and operating patterns, operating times and devastation conditions were tried to be revealed. Within the scope of the study, the mill and settlement data determined to belong to the field from the work named Çankırı Mufassal Tahrir Book dated 1579 were transferred to the tables. The localization of the mentioned settlements and mills was made by using 1 / 200.000 scale topography map. In addition, a field survey was carried out in Tosya city and its villages, and important information was obtained about the operating methods, duration and disappearance of the mills through interviews with local people. Then, the information obtained from the archive source and field research was evaluated by considering the literature. In the light of this information, the existence of 49 mills in Tosya sub-district was determined in $1578 / 1579$. It is observed that 40 of the mills included in the Tahrir register were actively operated, while 9 of them were destroyed. In addition, when the distribution of the mills is examined on the map, it is understood that the mills are concentrated in the river lengths located close to the settlements and in the areas suitable for elevation.
\end{abstract}

Keywords: Historical geography, Ottoman industry, mill, Tahrir book, Tosya. 


\section{Giriş}

İlkçağdan itibaren insanoğlu buğdayı ezmek için farklı yöntemler kullanmıştır. Ellerine aldıkları küçük düz kayalarla içi oyuk daha büyük kayaların arasında buğdayı sıkıştırmak suretiyle ezip un haline getirmişlerdir. Bu işlemde buğdayı un haline dönüştürmede kullanılan taşlara öğütme ve eyer taşları denilmektedir. Diğer öğütme taşları ise; dibek, dairesel dönen el ve değirmen taşlarıdır. Bu ezme işleminin yapıldığı alet ve makinalara, genel olarak en ilkelinden en modernine kadar hepsine değirmen denilmektedir (Yiğit 2007: 98). Değirmenin ilkel örnekleri, insan soyunun toprağa bağlandığı ve ilk tarım etkinliklerinin başladığı Neolitik Dönem'e (Cilalıtaş Devri’ne, M.Ö. 9000-5600) kadar uzanır. Tahıl tanelerini (buğday, arpa, mısır, çavdar) iki taş arasında ezerek un elde etmeye başlayan insanlar, bu işlemi geliş̧irerek ilk el değirmenlerini ortaya çıkarmışlardır (Kaçar vd. 2012: 11).

Enerjiye bağlı teknolojinin ilk dönemleri, insan ve hayvan gücüne bağlı olarak ortaya çıktığı bilinen bir gerçektir. Güç kaynağını insan ve hayvan gibi canlı unsurlardan alarak çalıştırılan araçlardan cansız enerji kaynaklarına geçiş sürecindeki kayda değer ilk gelişmeler, Milattan önceki yıllara tekabül etmektedir (Soyel 2009: 46). Nitekim insanlık tarihine bir canlının gücü

haricinde enerjisi kullanılarak işletilen ilk değirmen, M.Ö. 2000 yıllarında Çin Uygarlığı tarafından icat edildiği düşünülmektedir (Yiğit 2007: 99). Su gücünden istifade edilerek işletilen değirmen ise Anadolu'da (Strabon 1933, s.33), Yeşilırmak'ın bir kolu olan Kelkit çayı üzerinde M.Ö 1. yüzyılda Kaberia'da inşa edilmiştir (Landels 1996: 12) Yazılı kaynaklara göre bilinen ilk su değirmeni olarak karşımıza çıkan bu değirmen, Mithridates Krallığ1 dönemine aittir (Kaçar vd. 2012: 31).

Su değirmenleri icat edildiği ilk yıllardan M.S. 5. ve 6. yüzyıllara kadar yaygın bir şekilde kullanımı gerçekleşememiştir (Basalla 1998: 195). Su gücü ve dolayısıyla değirmenler Orta Çağ döneminde Avrupa'da, Roma İmparatorluğu'nun son dönemlerinde yaygın bir şekilde kullanıldığı görülmektedir (Bertoloni vd. 2006: 181; Basalla 1998: 195). Su değirmenlerinin bahsi geçen tarihlere kadar etkin ve yoğun bir şekilde kullanılmamasını Terry S. Reynolds teknik bilgi birikiminin Orta Çă̆'ın ilk dönemlerinde yeterli seviyelerde olmaması, Yunan ve Romalıların doğaya, işe ve teknolojiye karşı kendilerini kısıtlamaları, yeni bir teknolojiye yatırım yapmanın doğuracağı riskler gibi varsayımlara bağlamıştır. Bu varsayımları destekleyen bir diğer kanıt, Romalı toprak yöneticilerine, işgücünün kıtlaştığı ve toprağın pahalı olmaya başladığı dönemlerde su değirmenlerinin kullanılmasının tav- 
siye edilmesi (Reynolds 1998. akt. Basalla 1998: 197) olarak gösterilebilir. 11. yüzyılın sonlarına doğru vergi toplayıcıları tarafından kayıt altına alınan Domesday Book üzerinden yapılmış araştırmalara göre İngiltere' de 5624 değirmenin olduğu saptanmıştır. Bahsi geçen bu araştırma sonuçlarından da sadece Avrupa'nın İngiltere adasında, değirmenlerin ne denli artış gösterdiği gözler önüne serilmektedir (Gimpel 1976: 10).

Türklerin Anadolu'daki değirmen yapımı ve kullanımında elde etmiş oldukları teknik birikimleri, Orta Asya'dan mı getirmişlerdir, İslâm dünyasından mı öğrenmişlerdir, yoksa Anadolu'yu fethettikten sonra Romalılardan $\mathrm{m}$ almışlardır veya kendi birikimleri midir? bu konuda net bir karara varmak zordur (Yiğit 2007: 100). Fakat Türklerde değirmen kullanımının Hun Devleti'ne kadar dayandığı düşünülmektedir (Kaçar vd. 2012: 12) Hatta Wang Yen-Te'nin Uygur Seyahatnamesi'nde “Chinling dağlarından çıkan nehir, başşehrin bütün çevresini dolaşır, tarlaları ve meyve bahçelerini sular ve değirmenlerini işletir" şeklinde ifadelerinden Türklerde su değirmeni kullanımının Uygur Devleti (M.S. 745 - M.S. 840) dönemine kadar dayandığını söylemek yanlış olmayacaktır (İzgi 1989: 57). Sonuç olarak değirmelerin nerede ve ne zaman icat edildiği hakkında çeşitli bilgiler mevcuttur. Fakat değirmenlerle ilgili asıl öneme haiz konu, 18. yüzyıldaki Endüstri Devrimi'nin temellerinin atılmasında baş rollerden biri olarak karşımıza çıkmasıdır (Basalla 1998: 198). Dolayısıyla insanlık tarihi boyunca teknoloji ve sanayi gelişiminin önemli icatlarından ve dönüm noktalarından biridir.

Değirmen; buğday, arpa vb. gibi tahıl ürünlerini öğütmeye yaran araç ya da kurulu olduğu yapı olarak tanımlanmaktadır (Büyük Larousse 1986: 2940). Binlerce yıl önce ilk örnekleri ortaya çıkmaya başlayan değirmenler zaman içinde bilgi birikimin artmasıyla farklı türden enerji kaynaklarıyla entegre bir şekilde işletilebilir hale gelmiştir (Seçer 2002: 32) Değirmen taşının hareketini sağlaması bakımından sırasıyla hayvan, su, rüzgâr gücü; endüstri devrimiyle birlikte buhar, elektrik ve petrolden sağlanan enerjiler kullanılmıştır. Hayvan gücüyle çalışan değirmenler genellikle at, eşek, öküz, sığır ve deve gibi koşum hayvanlarıyla işletilen değirmenlerdir. Her bir değirmen taşının çalıştırılabilmesi için 4 hayvanın taş ile koordineli bir şekilde hareket etmesi gerekmektedir. Dolayısıyla işletme giderleri bakımından diğerlerine göre daha maliyetli olmuştur. Fakat Endüstri Devrimi’nden önce hayvan gücü ile çalışan değirmenler, su ve rüzgar gücüne göre tabii koşullardan daha az etkilenmeleri, işletme istikrarının sürdürülmesi açısından avantaj sağlamıştır (Kaçar vd. 2012: 15). Rüzgâr gücü ile çalışan değirmenlerin çalışma prensibi ise rüzgârın geldiği konuma göre kendini ayarlayan bir sistemin üstüne oturtularak çalışt1rllan değirmenlerdir (Seçer 2002: 36). 
Su değirmenleri dikey milli, yatay milli alttan çevrilen ve yatay milli üstten çevrilen çarklar olmak üzere temelde 3 çeşidi (Şekil 1) bulunmaktadır (Landels 1978: 12). Su gücü ile çalıştırılan değirmenlerin ilk örneklerinde dişli takımı ile hareket eden diğer bir deyimle yatay milli bir mekanizma yoktu. Yatay konumda dönen bir su çarkı, bu çarkın ortasına sabitlenmiş olan diklemesine bir mil yardımıyla değirmen taşına bağlantısı sağlanırdı (Gimpel 1976: 7). Su, sabitlenmiş oluk (Şekil 2) yardımıyla yüksek bir irtifadan çarkların üzerine aktarılıp hareket ettirilerek (Landels 1978: 12) değirmenin hareket etmesi sağlanırdı. Yatay eksenli çark ile istedikleri verimi elde edemeyen Romalılar, dikey eksenli su çarkını geliştirmişlerdir. İlk defa Romalı bir mühendisin kaleme aldığı bir kitapta rastlanılan dikey eksenli çarka sahip değirmenler M.Ö. 20 ve 11 yılları arasında kullanılmaya başlanmıştır (Koç 2004: 2). Fakat dikey çarklı değirmenler (üstten ve alttan çevrilen) suyun debisindeki değişikliklerden yatay çarklılara göre daha fazla etkilendikleri için âtıl halde kalabilmekteydi. Dolayısıyla Anadolu gibi eğimi yüksek alanlarda, uzak noktalardan su yolları ile getirilip çalıştırılabilen, yatay çarklı değirmenler tercih edilmiştir (Koç 2004: 3).

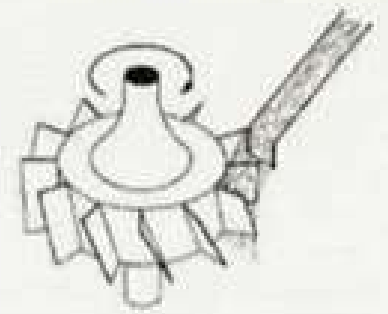

(a)

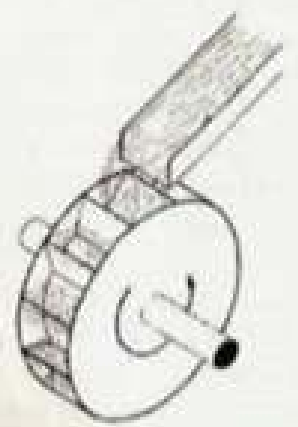

(c)

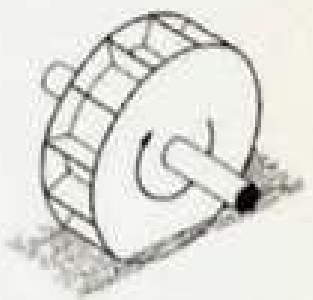

(b)

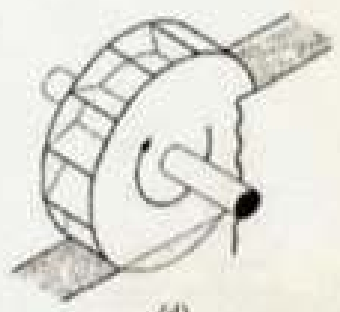

(d)

Şekil 1: a) Yatay Çarklı, b) Dikey Çarklı Alttan Çevirmeli, c) Dikey Çarklı Üstten Çevirmeli d) Gögüslemeli (Cotterel ve Kamminga, 2002: 49) 


\subsection{AMAÇ- KAPSAM- YÖNTEM}

$\mathrm{Bu}$ çalışmada, sanayi öncesi toplumlar için birer üretim ve sanayi faaliyeti olan değirmenler, XVI. yüzyıl Tosya nahiyesi örnekleminde tarihi coğrafya perspektifiyle ele alınarak şehir ve kırsal alandaki değirmenlerin yoğunluğu, dağılışı ve işletim şekilleri, işletim süreleri ve harap olma durumları ortaya konulmaya çalışılmıştır. Araştırmada öncelikle Keklik (2018) tarafindan transkripsiyonu gerçekleştirilerek yayınlanan 1579 Tarihli Çankırı Mufassal Tahrir Defteri eserden yerleşmeler, değirmencilik faaliyeti başta olmak üzere sahaya ait tüm sayısal veriler tablolara aktarılmıştır. Daha sonra sistematize edilen bu veriler ARC-GIS programı yardımıyla tematik haritalara aktarılıp dönemin değirmen dağılışı bölgenin doğal fiziki ve beşerî özellikleri göz önünde bulundurularak değerlendirilmiştir. Ayrıca çalışma sahasına gerçekleştirilen arazi araştırması sırasında değirmencilik faaliyetlerine ilişkin bilgiler toplanmış ve fotoğraflar çekilmiştir. Bu esnada değirmenlerin mekanik sistemlerine, işletim sürelerine ve harap hale gelmesine dair önemli bilgilere ulaşılmıştır.

\subsection{TOSYA ŞEHRI}

Tosya şehri geçmişten günümüze uzun süreli bir iskan merkezi olma özelliği göstermesinde, kurulmuş olduğu bölgenin doğal ortam şartları ve buna ek olarak beşerî unsurlarının etkili olduğu söylenebilir. Zira, Tosya'nın yerleşmiş olduğu vadiden akan Devrez Çayı ve kaynağını kuzeyde Ilgaz Dağları'ndan güneyde ise Geçmiş Dağları'ndan alan birçok akarsu kolu, getirmiş olduğu alüvyonlarla beraber bölgenin tarım potansiyelini yükseltmiştir. Tarımsal potansiyelin yanı sıra şehir, Kuzey Anadolu Fay Hattı'nın geçtiği bir oluğun üzerinde bulunmaktadır. Dolayısıyla ilk kurulduğu günden itibaren, Kuzey Anadolu'da doğuyu ve batıya birbirine bağlayan ana yolun bir parçası olmuştur. Aynı zamanda Tosya, Anadolu'nun doğusunu batısına bağladığı gibi, gerisindeki Tosya Ilgaz Geçidi marifetiyle Orta Anadolu'yu da Karadeniz'e bağlamaktadır. Tosya şehri, ulaşım açısından taşıdığı bu stratejik özellik sayesinde tarihte önemli bir menzil noktası hatta derbent yapılmıştır (İbret 2003: 6).

Yazılı kaynaklara göre Tosya şehrinin bulunduğu muhit ilk olarak Paflagonya adıyla geçmektedir (Kankal 2011: 5). Bölgeye yerleşen ilk yerleşimciler ise Kaşkarlar olarak bilinmektedir. Ardından bu bölge, Hititlerden Osmanlı Devleti'ne kadar geçen sürede (Romalılar, Persler gibi) birçok medeniyetin hakimiyeti altında kalmıştır (Bilgin 2003: 7). Tosya ve çevresinde ilk 
Türk hakimiyeti, 1071 Malazgirt Savaşı'nın ardından Anadolu'nun hızlı bir şekilde Türkler tarafından iskana sahne olduğu dönemlerde başlamıştır. $\mathrm{Bu}$ bölgeyi ilk olarak Emîr Dânişmend'e bağlı kumandanlardan Emîr Karategin 475'te (1082-83) fethetmiştir (Özaydın 1993: 269). Fatih Sultan Mehmed dönemiyle birlikte, Kastamonu ve Sinop fetihleri sirasinda, Tosya Osmanlı hakimiyetine girmiştir. Bahsi geçen dönemlerde Tosya'da hem bir derbendin var olması hem de İran'a yapılan seferler açısından geçiş güzergahı olmas1 Osmanlı hakimiyeti sonrasında da bölgenin stratejik ve ekonomik açıdan oldukça önemli bir merkez olduğunu göstermektedir (Özaydın 1993: 269). XVI. yüzyıl tahrir defterlerinde Tosya, Kengriri sancağına bağlı bir nahiye olarak karşımıza çıkmaktadır.

\subsection{YÜZYILDA TOSYA NAHIYESI}

Tosya nahiyesi, XVI. yüzyılın ilk yarısında Kengiri sancağına bağlı olan 9 idari üniteden ${ }^{1}$ biri olarak karşımıza çıkmaktadır. Bahsi geçen 9 idari ünite Kengiri, Kal'acık, Tosya, Çerkeş, Kurşunlu, Koçhisar, Kargu, Milan, Karıbazarı'ndan oluşmaktadır (Kankal 2011: 22). 1578/1579 yılında Tosya nahiyesine bağlı olduğu belirlenen 43 yerleşme ${ }^{2}$ bulunmaktadır (Tablo 1). Bu yerleşmelerden 42'si köy tüzel kişiliğine sahipken 1'i şehir hüviyetine haizdir (Harita 1). Söz konusu şehir Tosya nahiyesinin merkezi olan ve 24 mahallesi bulunan Nefs-i Tosya'dır. Tosya şehrine bağlı olan mahalleler s1rasıyla Hacı Seydi Ali, Cami Şerif, Hoca Fakih, Celal Efendi, Kargılu, Şeyh, Çifterli, Hacı Kemal, Dere, Hoca İmad, Hacı Sinan, Ak Mescid, Ahi Mustafa, Umur Mahmud, Pınarbaşı, Hacı Piri, Hoca Mehmed, Mescid-i Abdi Çelebi, Ahi Sinan, Sevim, Yeni, Kazancılar, İlyas Bey, Zimmiyan'dır (Keklik ve Keklik 2018: 107-114).

Kengiri sancağının XVI. yüzyılın ilk yarısından 1580 yılına kadar Keskin nahiyesinin de eklenmesiyle 10 nahiye ve o tarihten itibaren yüzyılın sonuna kadar ise 11 nahiyeden meydana geldiği de belirtilmektedir. Daha fazla bilgi için bkz. Ahmet Kankal, (2011). XVI. Yüzyılda Çankırı, Çankırı Belediyesi Kültür Yayınları, Çankırı.

Tablo 1'de 3, 7, 20 ve 24 numaralı hücrelerde bulunan köyler, Tahrir defterine beraber yazılmıştır. Buna istinaden tablo hazırlanırken kaynak defterde beraber yazılan köyler, aslına uygun olarak bir arada belirtilmiştir. Ayrıca 36 numaralı hücrede bulunan 3 köy, vakıf köyleri olduğu için referans alınan kaynakta belirtilmemiştir. Söz konusu köyler Kankal'ın (2011) hazırlamış olduğu XVI. Yüzyılda Çankırı adlı eserinde tespit edilmiş olup tabloya eklenmiş̧tir. Dolayısıyla diğer köylerle bir arada verilen Ağcakavak, Suluca, Kınık, Bağözü ve Kuşca yerleşmelerine; vakıf olduğu belirtilen Dilküşehri, Kösen, Ekincik'in de eklenmesiyle yerleşme sayısının 43'e çıktığı görülmektedir. 


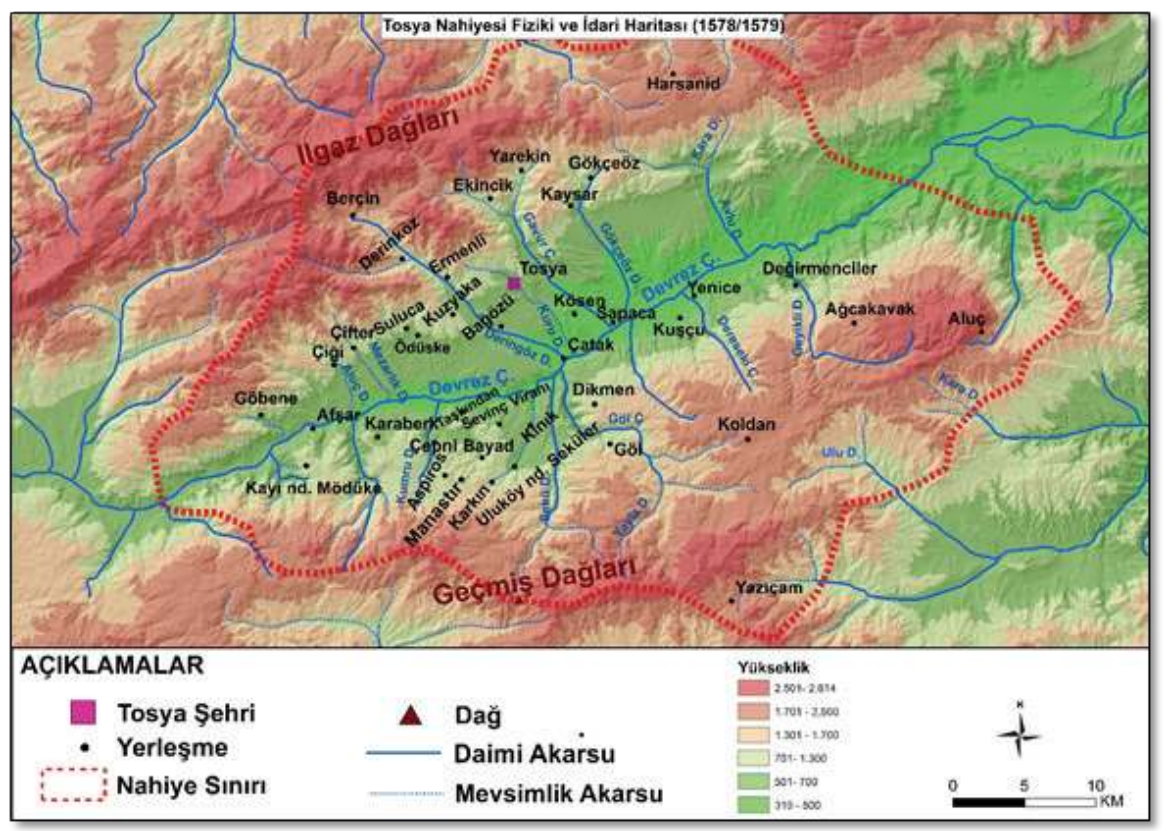

\section{Harita 1: Tosya Nahiyesi Fiziki ve İdari Haritast ${ }^{3}$ (1578/1579)}

Bilindiği üzere, Tahrir defterlerinin en ilgi çekici ve en fazla araştırmaya konu olan taraflarını demografik veriler oluşturmaktadır. Fakat söz konusu demografik veriler değerlendirilmeden önce dikkate alınması gereken önemli husus, tahrir defterlerinin merkezi idarenin talimatları doğrultusunda, timar sisteminin uygulanmış olduğu sancaklardaki beşerî ve iktisadi unsurların sayımlarının gerçekleştirildiği defterler olmasıdır. Dolayısıyla bu defterler, uygulandığ 1 idari birimlerdeki vergi potansiyelini görmek ve vergiye dair tüm bilgilerin kayıt altına alınması adına hazırlanan defterlerdir (Öz 1999: 41). Hal böyle olunca Tahrir defterlerinden nüfus tahmini yapılırken, çalış1lan sancağa dair hazırlanan kanunname ve bunun yanı sıra vergi mükellefi olarak kaydedilen kişilerin (caba, mücerred ve muaf) hususiyetlerine dikkat edilmesi gerekmektedir. Birçok araştırmacı tarafından bahsi geçen defterlerdeki vergi nüfusu/vergilendirilebilir nüfus üzerinden mevcut kişi sayısına dair hesaplamalar yapılmış ve çeşitli formüller geliştirilmiştir. Ele alınan bu çalışmada Tosya nahiyesinin 1578/1579 tarihindeki nüfus tahmini, Barkan'ın

Harita üzerinde 1578/1579 Tarihli Çankırı Mufassal Tahrir Defterinde adı belirtilen, Tosya nahiyesine bağlı yerleşim yerlerinin lokalizasyonu $1 / 25.000$ ve $1 / 200.000$ 'lik topografya haritaları üzerinde bulunan yerleşme isimleri, mevki isimleri ve arazi çalışmaları sırasında karşılaşılan fakat haritalarda belirtilmeyen mevkiler dikkate alınarak yapılmıştır. Harita üzerinde lokalizasyonu yapılmak için yeterli kanıt bulunamayan Dilküşehri, Yarımcakaya ve Kösen köyleri ise haritada belirtilmemiştir. 
(1953: 12) önermiş olduğu "hane başına 5 katsayısı” formülü tatbik edilerek çıkan sonuca nahiye genelindeki toplam muaf nüfusun eklenmesiyle hesaplanmıştır. Mücerredler ise bekar nüfusu teşkil ettiklerinden (Öz 2000 :21) zaten hane içerisinde sayılacağından söz konusu hesaplamanın dışında tutulmuştur.

Çalışmaya konu olan dönem itibariyle Tosya, 3.557 hane ve 98 muaf kişiden oluşan bir nahiyedir. Buna ek olarak, Kankal (2011: 98), XVI. Yüzyıl Çankırı Sancağ çalışmasında Tosya nahiyesine bağlı olduğunu tespit ettiği 3 vakıf yerleşmesinden bahsetmektedir. Söz konusu bu yerleşmeler 263 hane ve 8 muaf kişiden müteşekkildir. Bu haliyle Tosya nahiyesi nüfusunun ilgili tarihte, hane başına 5 katsayı formülüne istinaden 19.206 kişinden oluştuğu tahmin edilmektedir. Nahiyede bulunan yerleşmeler arasında "Nefs-i Tosya" olarak zikredilen nahiye merkezi 3.624 kişi ile en kalabalık nüfusa sahip yerleşmedir. Tosya şehri dışında Göl (1.382), Kuzyaka (1.055) ve Dikmen (1.036) köyleri kırsalda bulunup nüfusun en fazla olduğu yerleşmeler olarak karşımıza çıkmaktadır (Tablo 1). 


\begin{tabular}{|c|c|c|c|c|c|c|c|c|c|c|c|}
\hline Sira & Yerleşme & Hane & Mücerred & Muaf & Nüfus & Sura & Mahalle & Hane & Mücerred & Muaf & Nüfus \\
\hline 1 & Nefsi Tosya & 710 & 409 & 70 & 3620 & 19 & Dikmen K. & 206 & 63 & 6 & 1.036 \\
\hline 2 & Ermene K. & 106 & 41 & 2 & 532 & 20 & $\begin{array}{c}\text { Serinceviran } \\
\text { K. Kınık ile }\end{array}$ & 43 & 13 & 2 & 217 \\
\hline 3 & $\begin{array}{c}\text { Yazıçam K } \\
\text { Ağcakavak } \\
\text { ile }\end{array}$ & 57 & 0 & 0 & 285 & 21 & Sapaca K. & 89 & 70 & 0 & 445 \\
\hline 4 & Afşar K. & 44 & 47 & 0 & 220 & 22 & Taşkından K. & 12 & 0 & 1 & 61 \\
\hline 5 & $\begin{array}{l}\text { Uluköy nd. } \\
\text { Sekü }\end{array}$ & 120 & 40 & 3 & 603 & 23 & Koldan K. & 80 & 9 & 1 & 401 \\
\hline 6 & Aspiros K. & 92 & 26 & 0 & 460 & 24 & $\begin{array}{c}\text { Kayı, } \\
\text { Bağözz̈, } \\
\text { Kuşça K. }\end{array}$ & 110 & 97 & 2 & 552 \\
\hline 7 & $\begin{array}{l}\text { Özseki K. } \\
\text { Suluca ile }\end{array}$ & 145 & 69 & 0 & 725 & 25 & Kayser K. & 13 & 4 & 0 & 65 \\
\hline 8 & Bayad K. & 22 & 12 & 2 & 112 & 26 & Karaberk K. & 98 & 55 & 0 & 490 \\
\hline 9 & Berçin K. & 74 & 41 & 0 & 370 & 27 & Kuzyaka K. & 211 & 33 & 0 & 1.055 \\
\hline 10 & Çatak K. & 44 & 11 & 0 & 220 & 28 & Karkın K. & 51 & 10 & 1 & 256 \\
\hline 11 & Çiğe K. & 109 & 72 & 0 & 545 & 29 & Karı K. & 49 & 23 & 1 & 246 \\
\hline 12 & Yenice K. & 31 & 20 & 0 & 155 & 30 & Gökçeöz K. & 186 & 66 & 1 & 931 \\
\hline 13 & Aluç K. & 110 & 14 & 0 & 550 & 31 & Göl K. & 276 & 29 & 2 & 1.382 \\
\hline 14 & Çifter K. & 94 & 51 & 1 & 471 & 32 & Göbene $\mathrm{K}$. & 53 & 33 & 0 & 265 \\
\hline 15 & Çepni K. & 58 & 20 & 0 & 290 & 33 & Manastır K. & 12 & 2 & 0 & 60 \\
\hline 16 & Harsanid K. & 46 & 36 & 2 & 232 & 34 & $\begin{array}{c}\text { Yarımcakaya } \\
\text { K. } \\
\end{array}$ & 15 & 4 & 0 & 75 \\
\hline 17 & & 28 & 17 & 1 & 141 & 35 & Yarekin K. & 91 & 4 & 0 & 455 \\
\hline 18 & Derinöz K. & 72 & 34 & 0 & 360 & 36 & $\begin{array}{l}\text { Dilküşehri, } \\
\text { Ekincik, } \\
\text { Kösen }\end{array}$ & 263 & 175 & 8 & 1.323 \\
\hline & & & & & & & TOPLAM & 3.820 & 1.650 & 106 & 19.206 \\
\hline
\end{tabular}

Tablo 1: Tosya Nahiyesi Yerleşmeleri ve Nüfusu (1578/1579)

Kaynak: Keklik ve Kelik, 2018: 107-154.

Tosya nahiyesinin bulunduğu bölge genel itibariyle dağlık (Şekil 2) bir arazi yapısına sahiptir. Arazi yapısının arz ettiği bu duruma uygun olarak bağ ve bostan tarımı da gelişmiştir. Nahiye genelinde bahsi geçen bağ, bostan gibi yerlerden ve burada üretilen meyvelerden vergiler alınarak deftere nakdi karş1lığ1 kaydedilmiştir. Buna göre bağ (40.832 kuruş), bostan (2066 kuruş) ve meyve (5500) vergileri toplamda 48398 kuruşa ulaşmaktadır. Tosya nahiyesinde, ekonomisini zirai temeller üzerine kuran Osmanlı İmparatorluğu'nun en başta gelen ürünlerinden olan buğday ve arpanın da üretimi yapılmaktayd. Bununla birlikte buğday ve arpa değirmenlerde öğütülen en önemli ürünlerin başında gelmesi nedeniyle ayrı bir değerlendirme yapılmasında fayda vardır. Buğday ve arpadan alınan vergiler tüm nahiye genelinde müd ölçü birimine göre kaydedilmiştir. Buna göre nahiye genelinde toplamda 410,6 
müd ${ }^{4}$ buğday, 448,6 müd de arpa vergisi alınmıştır. Alınan bu vergilere göre Tosya nahiyesinde yaklaşık $1.685 .033^{5}$ kilogram buğday ve 1.792 .000 kilogram arpa üretimi yapılmıştır. ${ }^{6}$ Nahiye genelinde elde edilen hububatın ticareti, ayni olarak ödenen vergiler, tohumluğu ve bunun gibi tasarruf şekilleri bir kenara bırakılacak olursa kalan kısmının insanların kendi yiyeceği için un haline getirilmesi bakımından önemlidir. Zira buğday ve arpa Osmanlı ekonomisinin önemli gelir kalemlerinden ikisini oluştururken halkın ve hayvanların en önemli gıda ürünlerini teşkil etmekteydi.

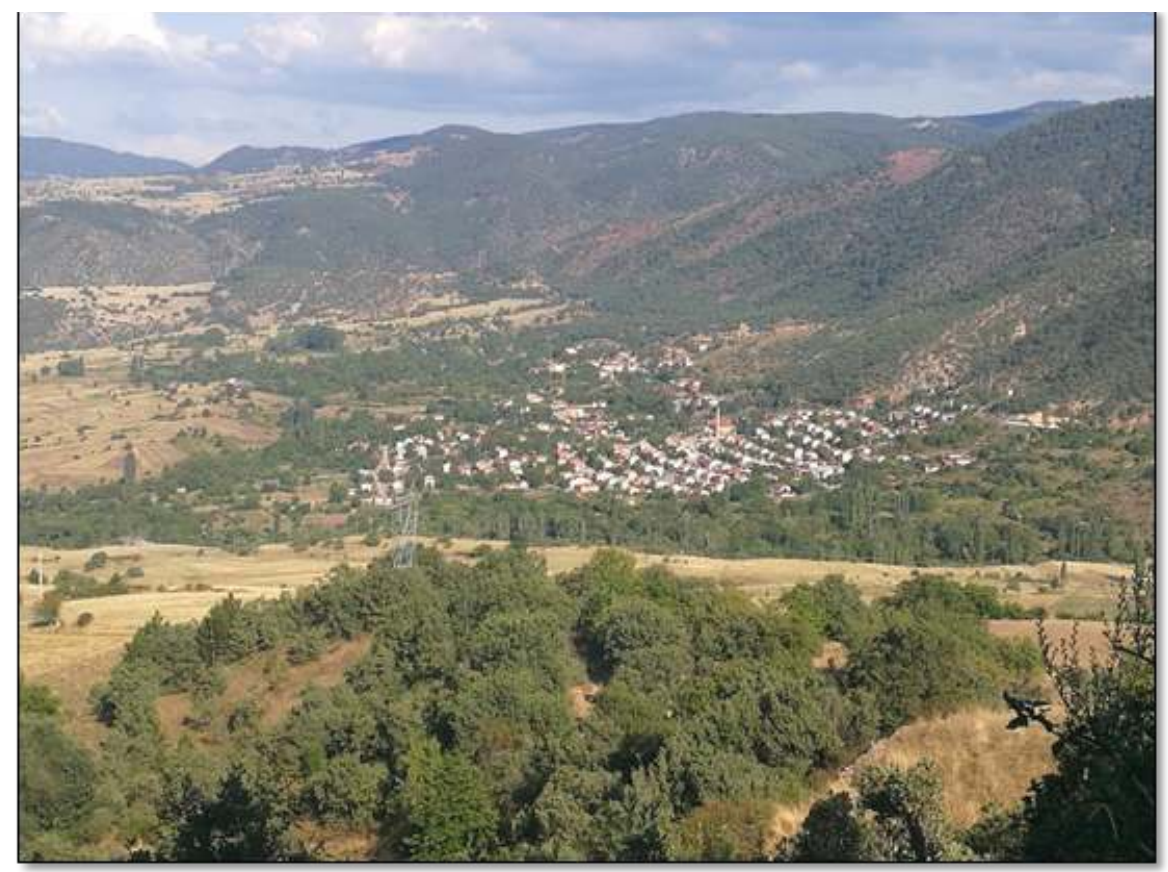

Şekil 2: Geçmiş Dağlart ve Sekiler Köyü'nden Bir Görünüm

Tosya hem Orta Anadolu'yu Karadeniz'e hem de İstanbul'u İran'a bağlayan ticaret yolların üzerinde bulunması nedeniyle ekonomik açıdan önemli

$4 \quad 1$ müd: 20 kile, 1 kile: 25,656 kilogram. Daha fazlası için bkz. W. Hinz, (1990), İslamda Ölçü Sistemleri, Edebiyat Fakültesi Basım Evi, İstanbul; Çankırı sancağında öşür 1/8 olarak kabul edilmiştir. Kankal, (2009). XVI. Yüzyılda Çankırı, s. 153.

5 Alınan 1/8 vergi oranı ve diğer katsayıları hesaba katarsak 410x8=3.284 müd buğday Tosya nahiyesinde üretimi yapılmıştır. Söz konusu 3.284 müd buğday, $3.284 \times 20=65.696$ kile buğday ve $65.696 x 25,656=1.685 .033$ kilograma tekabül etmektedir. Aynı hesaplama arpa üretimi üzerinden yapıldığında ise 792.000 kilogram arpa üretimi yapıldığını göstermektedir.

6 Buradaki hesaplamalar Tosya nahiyesinde alınan 1/8 vergi oranı, müd ölçü biriminin kaç kileye tekabül ettiği ve kilenin de kaç kilogram olduğu dikkate alınarak yapılmıştır. 
bir hüviyete sahipti olmuştur (İbret 2003: 15). Tosya'da H.993'te (M.1585) bedesten yapılması (Faroqhi 2000: 33) o dönemlerde nahiyenin ticari hayat1 hakkında önemli ipuçları vermektedir. Elde edilen verilere göre Tosya nahiyesinde ticaretten "Tahmis-i Kahve ve Şemhane" (19.500 kuruş), "İhtisab-1 ${ }^{7}$ Tosya" (5.000 kuruş), "Bac-1 Bazar" (13.000 kuruş), "Bac-1 Keyl-i Bazar-1 Nefs-i Tosya" (10.000 kuruş) ve "Cendere Der Nefs-i Tosya ${ }^{10 "}$ " (25.000 kuruş) adlarıyla vergiler alınmıştır. Buna göre Tosya'da 1578/1579 senesinde ticari olarak 53 bin kuruş vergi alınmış ve bu miktar nahiye genelinde alınan tüm vergilerin \%18,50'sine tekabül etmektedir. Bac ve ihtisab adıyla alınan bu vergilerden elde edilen gelirlerin yüksek oluşu bir bölgedeki şehir ve ticaret hayatının gelişmiş olduğunun göstermektedir (Yediyıldız 1985: 129). Tosya'nın ticari hayatının bağlı bulunduğu sancak merkezinde daha yüksek oluşu (Kankal 2009) Tosya şehrinin ekonomik açıdan önemini gözler önüne sermektedir.

Kahve, değirmen, şemhane ve cendere gibi işletmeler her ne kadar ticari açıdan değerlendirilse de üretim yapan birer sanayi işletmesi kapsamına da girmektedirler. Bunlar arasında tarımsal faaliyetlerin tamamlayıcısı olarak görülen değirmenler, insanların en gerekli besin maddelerinden olan unun üretilmesinde kullanılmaktadırlar. Dolayısıyla sanayi öncesi devlet yapıs1 kimliğini yansıtan Osmanlı Devleti için söz konusu işletmeler birer sanayi faaliyeti olarak değerlendirilebilir. Konuya bu açıdan bakıldığında Osmanlı döneminde değirmenlerin sanayi faaliyeti olarak önemli bir yeri olduğu değerlendirilmektedir (Gümüşçü 2002: 184).

İhtisab kelimesi hesap sorma, hesaba çekme ve sorumlu tutma anlamlarına gelmektedir. Osmanlı Devleti'nde İslam hukukuna göre bir şehir halkının şer'i emir ve yasaklarına uymasını sağlamak, çarşı ve pazarı kontrol etmek, şeriata ve örfe göre hareket etmeyenleri cezalandırmakla görevli teşkilat, belediye görevini yapan kuruluştur. Bu işi yapan kişiye de muhtesip denilirdi. Muhtesip sanat erbabının narhlarına bakmak, kile, arşın ve sair ölçüler ile terazi ve kantarları muayene edip düzgün ölçüler kullanmayan ve satışlarda hile yapanları cezalandırmak vazifesiyle mükellef olan memurdur. Daha fazla bilgi için bkz. M. Z. Pakalın, (1993). Osmanlı Tarih Deyimleri ve Terimleri Sözlüğ̈̈, Millî Eğitim Bakanlığı Yayınları, İstanbul, C. 2, s. 573.

Kanunname metinlerinden ve diğer yazılı kaynaklarda da ifade edilen "bac-1 bazar" vergisi, Osmanlı Devleti'nde ekseriyetle şehir pazarlarından alınan vergiler için kullanılmıştır. Celal Yeniçeri, (1991)."Bac", Türkiye Diyanet Vakfı İslam Ansiklopedisi, Türkiye Diyanet Vakfı Yayınları, İstanbul, C. 4, s. 411-413.

9 Muhtesip'in, pazarda satılacak olan hububat tarzında ürünlerin kantara çekmesi anında alınan vergiye "Bac-1 Keyl-i Bazar" denilmektedir. Kankal, (2009). XVI. Yüzyılda Çankırı, s. 153

Bir çeşit baskı tezgâhı olarak da ifade edilen Cendere, Sof ve muhayyerlerinin boyanmak maksadıyla getirildiği tezgahlardır. Kankal, (2009). XVI. Yüzyllda Çankırl, s. 153. 


\subsection{TOSYA NAHIYYESI'’NDE SU DEĞİRMENLERİ (1578/1579)}

Bölgenin coğrafi yapısı gereği Devrez Çayı etrafına kümelenen köylere paralel olarak değirmenlerin dağıllışı da bu durumdan etkilenmiştir. Zira ilgili tarihte Devrez Çayı'na bağlanan hemen hemen her akarsu kolu civarına bir veya birden fazla köy kurulmuş olup bu köylere çeşitli sayılarda değirmen işletmeleri inşa edilmiştir. Hatta şartların uygun olduğu ve değirmen işletmesine talebin fazla olduğu yerleşmelerde değirmen sayısının 5-6'ya kadar ulaşabildiği görülmektedir.

Osmanlı' da işletilen su değirmenleri, dönemlik ve daimî olarak ikiye ayrılabilir. Zira bu durum, değirmenin kurulmuş olduğu akarsuyun akış rejimiyle yakından alakalıdır. 1578/1579 senesinde Tosya nahiyesine bağlı olduğu tespit edilen değirmenlerin tamamı su değirmenleri (Şekil 3) olarak görülmektedir ve bu değirmenlerin bazıları, her ne kadar Tosya' da bulunan daimî akarsular üzerinde inşa edilmiş olsalar da neredeyse tamamına yakını dönemlik olarak işletilmiştir. Çünkü mevsimsel olarak suyun debisinde meydana gelen azalmalar ve kışın suyun zaman zaman donması gibi sebepler değirmenlerin yıl boyu işletilmesini engelleyen faktörler olarak ortaya çıkmıştır.

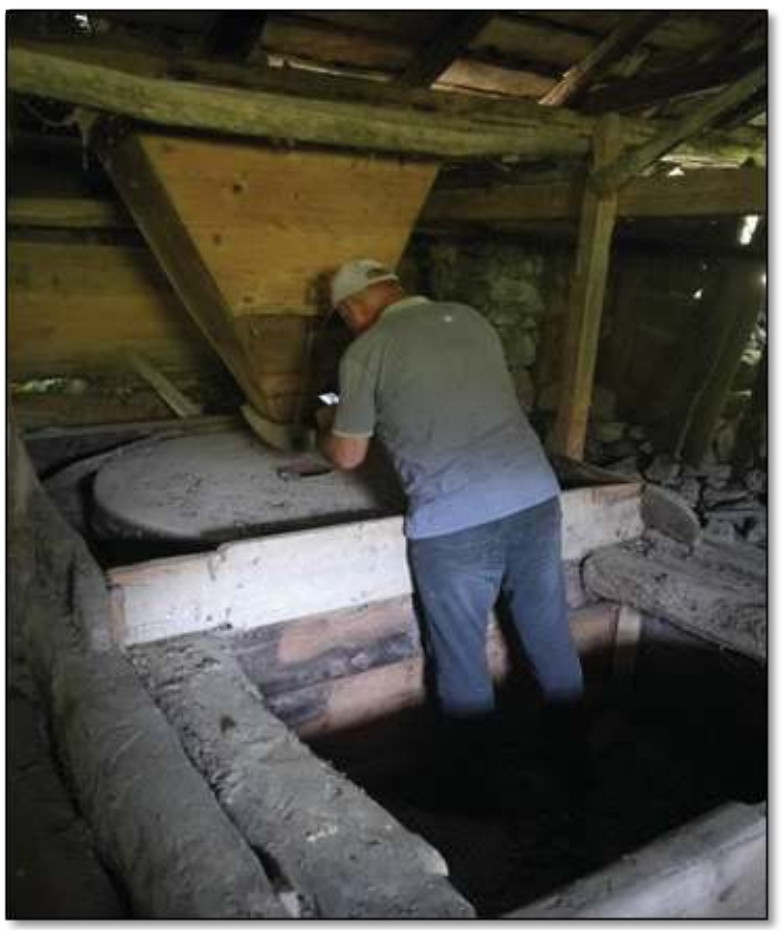

Şekil 3: Kullanılabilir Durumda Olan Yatay Çarklı Su Değirmeni (Ermenli) 
Osmanlı'da işletilen değirmenleri işlevleri bakımından un, ding, yağhane ve tahinhane değirmenleri olarak temelde üç farklı kategoriye ayırmak mümkündür. Un değirmenleri, genellikle zahire öğütmek için kullanılan değirmenlerdir. Ding (Şekil 4) değirmenleri çeltik tarımı yapılan bölgelerde çeltiği kabuğundan ayırmak için kullanılan değirmenlerdir. Tosya, Osmanlı döneminde de olmak üzere günümüze kadar çeltik tarımının yapıldığı bir bölgedir ve dolayısıyla ding değirmenlere bu bölgede rastlamak mümkündür. Yağhanelerde bulunan değirmenler ise susam ve zeytin gibi mahsullerden yağ elde etmek ya da tahin elde etmek amacıyla kullanılmıştır (Yiğit 2007: 107). 1578/1579 y1l Tosya'da tespit edilen değirmenler için hangi kategoride yer aldıkları konusunda herhangi bir sonuca ulaşılamamıştır. Zira çalışmada kullanılan belgeler üzerinde değirmenlerin işlevine dair herhangi bir ayrım yapılmamıştır.

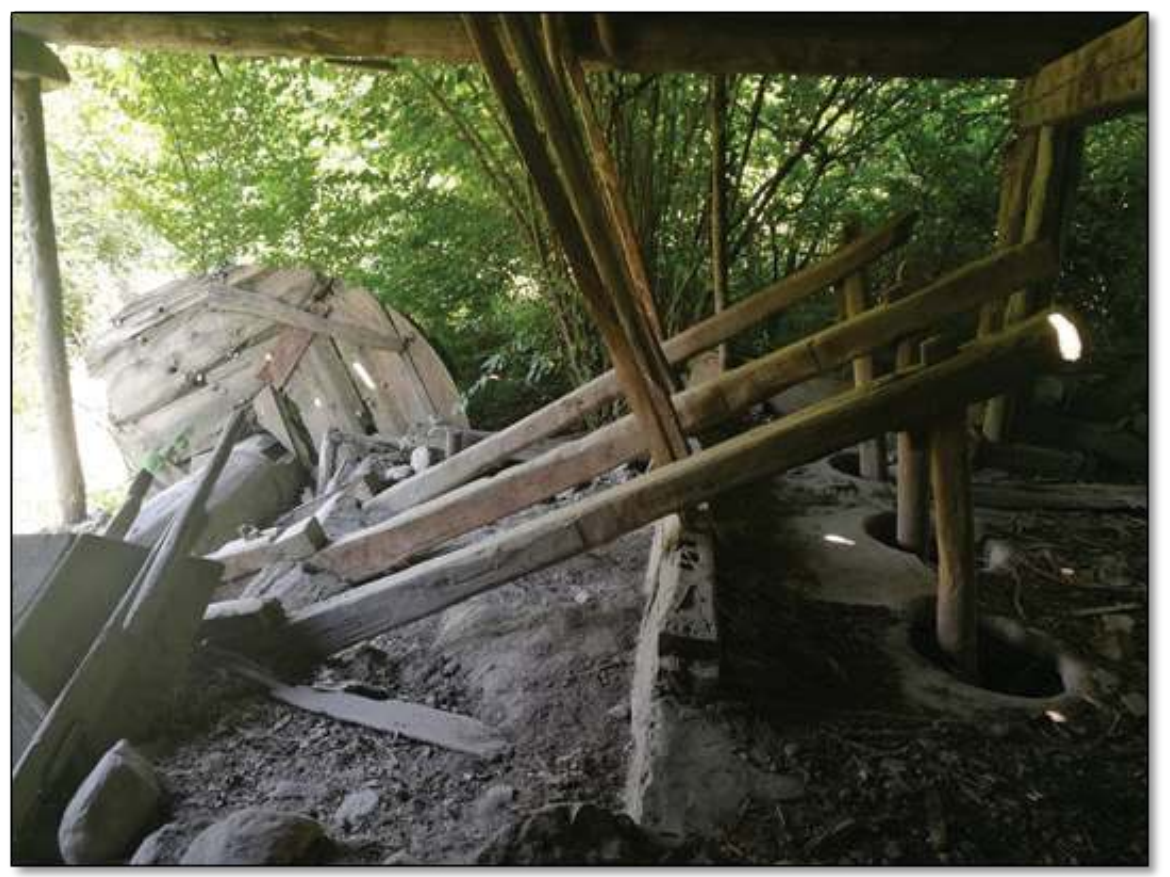

Şekil 4: Bulgur (Ding) Değirmeni ${ }^{11}$ (Kuzyaka Köyü)

\footnotetext{
$11 \quad$ Yerel halkın Ding diye tabir ettiği bulgur değirmenleri de yapılan arazi araştırması sırasında gözlemlenmiştir. Tosya'da karşılaşılan yatay çarklı değirmenlerden farklı olarak bu değirmenler dikey çarklı bir mekanizma sayesinde çalıştırılmaktadır. Dikey çarka bağlı olan kalın ve uzun bir mil, suyun çarkın haznelerine kuvvet uygulaması suretiyle kendi ekseni etrafinda dönmekte ve mile sabitlenmiş olan kazık dedikleri çentikler her bir dönüşünde bağlı olduğu çekiçleri dikey yönde hareket ettirerek hazneye düşmesini ve haznenin içindeki malzemenin istenilen kıvama gelmesini sağlamaktadır.
} 
Yapılan arazi araştırması kapsamında değirmenlerin işletim sürelerine dair çeşitli bilgiler elde etmek mümkün olmuştur. Ermenli köyünde ikamet eden Hacı Mehmet değirmenlerin işletim süresiyle ilgili sorulan soruya "Yazın sıcakları vurmaya başladığı zaman bizim derenin (Deringöz D.) suyu azalır, yukarıdan çevrilen bende (su yolunu çevirmek için çekilen set) gelen su azaldığı için haliyle arktaki (değirmene çekilen su yolu) su da değirmeni döndürmeye yetmez" şeklinde cevap vererek mevsimsel faktörlerin değirmenlerin işletilmesine etkisini vurgulamıştır. Nitekim yaz mevsimi yapılan arazi gözlemleri sırasında tespit edilen değirmenlerin bulunduğu çoğu akarsuyun kuruduğu görülmüştür (Şekil 5).

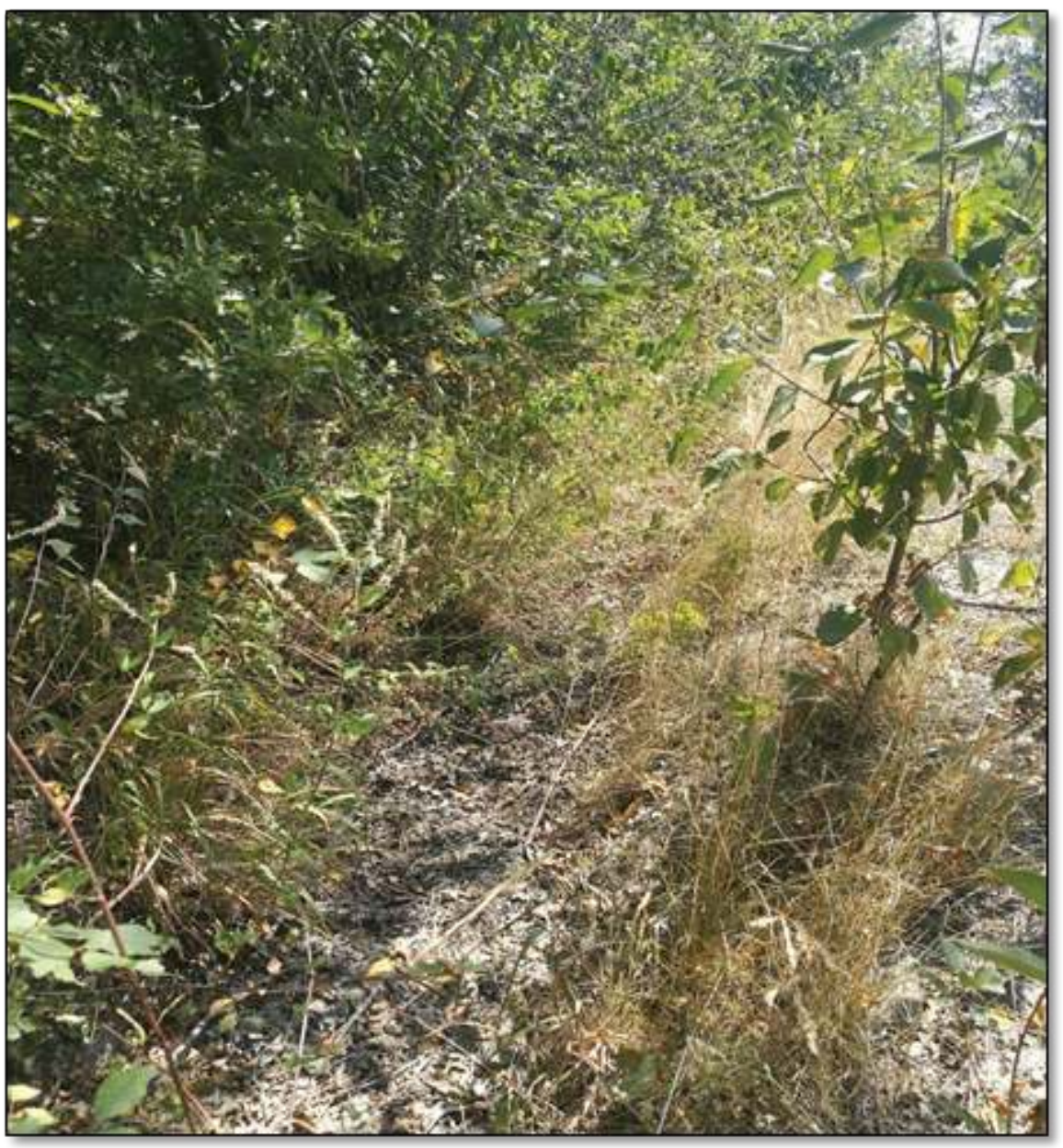

Şekil 5: Kurumuş Su Yolu (Ermenli Köyü) 
1578/1579 yılında Tosya nahiyesine bağlı olduğu tespit edilen yerleşmelerin 21'inde (Tablo 2) değirmen olduğu görülmektedir ve söz konusu bu yerleşmelere ait toplamda 49 değirmen bulunmaktadır. Başka bir deyişle, değirmen bulunan yerleşmeler (43 yerleşmenin 21'i) üzerinden yapılacak hesaplamaya göre, yerleşme başına 2,3 değirmen düşmektedir. Söz konusu hesaplamadan farklı olarak değirmen olsun olmasın her yerleşmeye 1,1 değirmen düşmektedir yani neredeyse tam tersi bir hal almaktadır. $\mathrm{Bu}$ durumun ortaya çıkmasında bazı yerleşmelerin birden fazla değirmeni bünyesinde barındırması ile ilgilidir. Birden fazla değirmenin bulunduğu yerleşmeler arasında Tosya şehri aktif olarak çalıştığı belirtilen 6 değirmen ile nahiye genelinde en fazla değirmenin bulunduğu yerleşmedir. Tosya şehrinde bulunan 6 değirmenle ilgili dikkati çeken diğer bir husus, nispeten dar bir alanda 6 değirmenin bulunmasıdır. Söz konusu yoğunluğu, şehir merkezinde bulunan 24 mahallenin varlığı, nüfusun diğer yerleşmelere oranla daha fazla olması ve değirmeni olmayan yakın köylerin buraya gelmeleri şeklinde açıklamak mümkündür. Dolayısıyla değirmenlere olan ihtiyaç talepkâr nüfusa göre artış göstermiş olmalıdır. Ayrıca, Tosya şehrinin kurulmuş olduğu saha konum itibariyle engebeli bir yap1 arz etmesi ve buna paralel olarak akarsuların değirmenleri dönemsel olarak çalıştırabilecek güçte olması söz konusu yoğunluğu açılayacak diğer etkenlerdir. Tosya şehri haricinde en fazla değirmen bulunduran yerleşmeler (harap değirmenler de dahil), 5 değirmen ile Uluköy, 4'er değirmen ile Derin Öz, Dikmen ve Kuzyaka şeklinde sıralanmaktadır. Çatak, Çifter, Göl, Gökçeöz, Göbene, Koldan, Kayı ve Bağözü (Tablo 2) köyleri ise sadece 1 değirmen işleten köyler olarak karşımıza çıkmaktadır.

Değirmenlerin dağılışı açısından değerlendirilmesi gereken diğer bir husus, sahanın iki yakasını oluşturan Geçmiş ve Ilgaz dağları üzerindeki değirmen sayısı ve yoğunluğudur. Yani iki dağ silsilesi arasında değirmen sayısı ve yoğunluğu bakımından farklılık gösterip göstermediği meselesidir. Buna göre Ilgaz Dağları üzerinde bulunan yerleşmelerde toplam 27 değirmen bulunurken Geçmiş Dağları üzerinde 13 değirmen olduğu saptnamıştır. Başka bir deyişle Ilgaz Dağları üzerinde bulunan değirmen sayısı Geçmiş Dağları'na göre 2 kat fazladır. Bu durumda Geçmiş Dağları üzerinde her ne kadar daha fazla yerleşme (22 köy) olsa da Ilgaz Dağları üzerinde daha fazla sayıda değirmenin bulunması, sahanın yeryüzü şekilleri, arazinin eğim ve yükselti durumu bakımından daha uygun şartlar taşımasına, kaynağını Ilgaz Dağları üzerinden alan akarsuların akış rejimine ve debisine bağlanabilir (Harita 2). 


\begin{tabular}{|c|c|c|c|c|c|c|}
\hline \multirow[b]{2}{*}{ Sira } & \multirow[b]{2}{*}{ Yerleşim Yeri } & \multicolumn{2}{|c|}{ Aktif Değirmen } & \multicolumn{2}{|c|}{ Harap Değirmen } & \multirow[b]{2}{*}{$\begin{array}{l}\text { Alınan } \\
\text { vergi }\end{array}$} \\
\hline & & $\begin{array}{c}\text { Değirmen } \\
\text { Sayısı }\end{array}$ & $\begin{array}{l}\text { Değirmen Taşı } \\
\text { (Adet) }\end{array}$ & $\begin{array}{c}\text { Değirmen } \\
\text { Sayı1s1 }\end{array}$ & $\begin{array}{l}\text { Değirmen } \\
\text { Taşı }\end{array}$ & \\
\hline 1 & Nefs-i Tosya & 6 & 11 & & & 280 \\
\hline 2 & Ermenli K. & 2 & 6 & 1 & 1 & 150 \\
\hline 3 & Ulu Sekü K. & 3 & 4 & 2 & 2 & 95 \\
\hline 4 & Aspiros K. & 3 & 4 & & & 55 \\
\hline 5 & Berçin K. & 1 & 4 & 1 & 3 & 60 \\
\hline 6 & Çatak K. & 1 & 2 & & & 60 \\
\hline 7 & Aluç K. & 2 & 6 & & & 180 \\
\hline 8 & Çifter K. & 1 & 3 & & & 45 \\
\hline 9 & Çepni K. & 2 & 3 & & & 40 \\
\hline 10 & Harsanid K. & 2 & 6 & & & 225 \\
\hline 11 & Derin Öz K. & 3 & 8 & 1 & 3 & 95 \\
\hline 12 & Dikmen K. & 3 & 8 & 1 & 2 & 175 \\
\hline 13 & Kuz Yaka K. & 3 & 6 & 1 & 1 & 120 \\
\hline 14 & Karı K. & 1 & 3 & 1 & 1 & 45 \\
\hline 15 & Göl K. & 1 & 1 & & & 60 \\
\hline 16 & Gökçe Öz K. & 0 & 0 & 1 & 1 & 0 \\
\hline 17 & Göbene K. & 1 & 1 & & & 15 \\
\hline 18 & Yarekin K. & 2 & 4 & & & 55 \\
\hline 19 & Koldan K. & 1 & 2 & & & 40 \\
\hline 20 & Kayı K. & 1 & 1 & & & 15 \\
\hline \multirow[t]{2}{*}{21} & Bağ Özü K. & 1 & 2 & & & 30 \\
\hline & Toplam & 40 & 85 & 9 & 14 & 1840 \\
\hline
\end{tabular}

Tablo 2: Tosya Nahiyesinde Değirmen ve Bab ${ }^{12}$ Sayllarl ile Alınan Vergi Miktarlart

Değirmenler gerek doğal çevre özelliklerinden gerekse beşerî unsurlardan en azından Tosya nahiyesine bağlı yerleşmeler kapsamında düzensiz bir dağ11 ım göstermektedir. Dolayısıyla bazı yerleşmede tek bir değirmen ile karşılaşırken bir başka yerleşmede 6 değirmene kadar çıktığı görülmektedir (Harita 2). Söz konusu düzensiz dağılımda olduğu gibi değirmenlerin işlemesini sağlayan değirmen taşlarında da farklılıklar mevcuttur. Buna göre 1578/1579 y1lında nahiyede bulunan 49 değirmenin toplam 99 ünitesi (değirmen taşı) bulunmaktadır. Yani nahiye genelinde bulunan her bir değirmen başına ortalama 2,1 ünite/taş düşmektedir. Fakat ortalama değer bir kenara bırakılıp “en

\footnotetext{
12 Değirmende işleyen değirmen taşı tahrir defterlerine "Bab" şeklinde kavramsallaştırılarak kaydedilmiştir. Dolayısıyla değirmenler için kullanılan "Bab" tabiri, değirmenlerde işletilen her bir üniteye karşılık gelmektedir.
} 
az" "en çok" kıyaslaması yapıldığında değirmen başına tek değirmen taşı düşebilirken, değirmen başına 4 değirmen taşına kadar çıktığı da görülmektedir. Bu konuya Berçin köyünde bulunan değirmen örnek verilebilir (Tablo 2). Söz konusu durumun ortaya çıkmasında arz talep ilişkisi ve doğal çevre koşullarının etkili olduğu söylenebilir.

Hane üzerinden yapılacak hesaplamaya göre, nahiyede bulunan 3557 hanenin her 89'una 1 değirmen düştügü görülmektedir. Söz konusu hesaplamaya yerleşmeler üzerinden bakılacak olunursa farklı sonuçlar ortaya çıkmaktadır. Buna göre nahiye genelinde değirmen başına en fazla hanenin düştüğü yerleşme 276 ile Göl yerleşmesidir. Göl yerleşmesini 118 hane ile Tosya şehri ve 94 hane ile Çifter yerleşmesi takip etmektedir. Değirmen başına en az hanenin düştügü köyler ise Harsanid (23), Derinöz (24), Çepni (29) ve Aspiros (30) şeklindedir. Ayrıca belirtmek gerekir ki, değirmen bulunmayan yerleşmelerden gelen kişiler de göz önünde bulundurulduğunda değirmen başına düşen hane sayısında farklı durumlar ortaya çıkabilir.

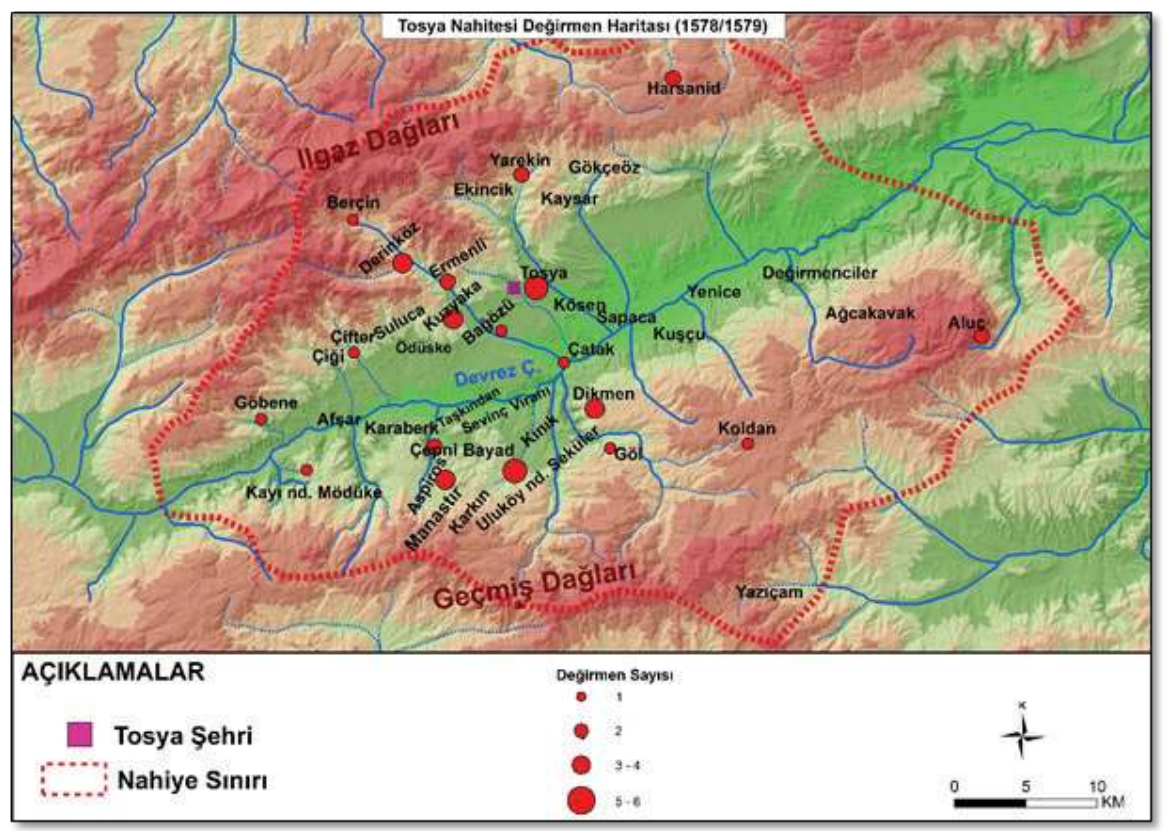

Harita 2: Tosya Nahiyesi’nde Değirmenlerin Dağ 11 ş13 ${ }^{13}(1578 / 1579)$

13 Haritada değirmen bulunan köylerin değirmen bulunmayan köylerle karışıklığını engellemek için sadece değirmen bulunan köylerin isimleri belirtilmiştir. 
Arazi araştırmalarında, değirmen bulunmayan yerleşmelerde ikamet eden halkın ihtiyaç halinde nasıl bir yol izlediklerine dair bilgiler de elde edilmiştir. Nitekim Kayı köyünde konuyla ilgili yapılan mülakatta, değirmen olmadığı durumda izlenen yol ve çekilen sorunlar ile ilgili tecrübeler şu şekilde ifade edilmiştir:

"Değirmende un öğüttüğümüz sıralar bizim köye en yakın Çepni köyünde değirmen vardı. 7-8 köyün adamı bu değirmende ununu öğütmeye gelirdi. Buğdayını arpasını alan merkeplere(eşek) yükler yollara düşerdik. Un öğütmek için sıra alırdık, bu sıraya göre giderdik ve o gün sadece senin unun öğütülürdü. Tüm kışlı̆̆ı o gün (sıra alındığı gün) çıkarırdık. Köyünde değirmen olması büyük bir lütuf çünkü gidilmesi gereken bir yol vardı ve tüm gün yanımıza aldığımız erzak ile günü çıkarmaya çalışırdık. Zaten gittiğimiz yol uzak ve yama (yokuş) idi, perişan oluyorduk".

Gümüşçü ile ve Çınar (2002) çok yakın tarihlere kadar bu şekilde olagelen durumu "Geçmişte çok daha önemli olan ve dönemin şartlarına göre "sanayi" tesisi sayılan değirmenler, bulunan iskân merkezleri için bulunmayanlara göre bir üstünlük vasıtası durumundaydı" (184) şeklinde ifade ederek değirmen olan yerleşmelerin değirmen olmayanlara göre önemine dikkat çekmişlerdir.

\subsection{DEĞİRMEN ÇALIŞTIRMA/IŞLETIM SÜRELERI}

$\mathrm{Su}$ değirmenleri, kurulmuş olduğu akarsuyun bulunduğu arazi yapısı ve iklimine göre işletilme sürelerinde farklılıklar söz konusudur. Bu bağlamda Tosya'da arazi çalışmaları esnasında yapılan mülakatlarda değirmenlerin bakı ve iklim gibi sebeplerden ötürü işletilme sürelerinin farklılık gösterdiği sonucuna ulaşılmıştır. Bakıdan kaynaklı olarak kışın kuzey yamaçlar don olayının yaygın görüldüğü yerler olarak karşımıza çıkmaktadır. Dolayısıyla değirmeni harekete geçirecek olan akarsuyun donması, çalışma sürelerini kısıtlamıştır. Aynı şekilde iklimin o bölgede kurak - yarı kurak karakter göstermesi mevsimlik akış gösteren akarsuların oluşmasına neden olmakta ve dolayısıyla değirmenin çalışmasını kısıtlamaktadır. Nitekim Devrez Çayı'na bağlanan ve kaynağını Ilgaz ve Geçmiş dağlarından alan yan kollar epizodik akışlı ve sel karakterli akarsulardır (Tanrıkulu 1999: 8-9)

Tahrir defterlerine göre nahiye genelinde aktif olarak çalıştığ 1 belirtilen 40 değirmen bulunmaktadır. Çalıştırıldıkları süreleri daha anlamlı bir bütün halinde verebilmek adına 1-4 ay, 5-8 ay ve 9-12 ay olarak çalışma sürelerine göre değirmenler sınıflandırılmıştır. Böylelikle işletim sürelerine dair bazı fikirler öne sürebilmek mümkün olmaktadır. Tahrir kayıtlarında "mah" olarak ifade edilen işletim sürelerine göre değirmenlerden 27'si en fazla 1-4 ay 
arasında aktif kalmıştır. Diğer bir ifadeyle bahsi geçen dönemde işletilen 40 değirmenin \%67,5'i 1-4 ay arasında çalıştırılmıştır. Geriye kalan 13 değirmenden 11'i (\%27,5) 5-8 ay civarında işletilirken Harsanid ve Göl köylerinde bulunan 2(\%5) değirmenin yıl boyu aktif olduğu görülmektedir.

\begin{tabular}{|l|c|c|c|}
\hline Yerleşmeler & $\mathbf{1 - 4} \mathbf{A y}$ & $\mathbf{5 - 8} \mathbf{A y}$ & $\mathbf{9 - 1 2} \mathbf{A y}$ \\
\hline Tosya Merkez & 2 & 4 & 0 \\
\hline Ermene & 1 & 1 & 0 \\
\hline Uluköy & 2 & 1 & 0 \\
\hline Aspiros & 3 & 0 & 0 \\
\hline Berçin & 1 & 0 & 0 \\
\hline Çatak & 0 & 1 & 0 \\
\hline Aluç & 0 & 2 & 0 \\
\hline Çifter & 1 & 0 & 0 \\
\hline Çepni & 2 & 0 & 0 \\
\hline Harsanid & 1 & 0 & 1 \\
\hline Derinöz & 2 & 1 & 0 \\
\hline Dikmen & 2 & 1 & 0 \\
\hline Kayı & 1 & 0 & 0 \\
\hline Bağözü & 1 & 0 & 0 \\
\hline Koldan Köyü & 1 & 0 & 0 \\
\hline Kuzyaka & 3 & 0 & 0 \\
\hline Karı & 1 & 0 & 0 \\
\hline Göl & 0 & 0 & 1 \\
\hline Göbene & 1 & 0 & 0 \\
\hline Yarekin & 2 & 0 & 0 \\
\hline Toplam & $\mathbf{2 7 ( \% 6 7 , 5 )}$ & $\mathbf{1 1}(\mathbf{\% 2 7 , 5 )}$ & $\mathbf{2 ( \% 5 )}$ \\
\hline
\end{tabular}

Tablo 3: Tosya Nahiyesi Değirmen İşletim Süreleri (1578/1579)

\subsection{DEĞİRMEN VERGISII}

Tosya'nın bağlı olduğu Kengiri Sancağı Kanunnamesi'nde değirmen vergileri için "haliya kanun-1 kadime ri' ayet olunub ayda beşer akçe hesabınca tamam y1l yürür değirmen altmış akçe ve altı ay yürür değirmen otuz ve üç ay yürür değirmene on beş akçe resm kayd olundu" ifadeleri kullanılmıştır (Keklik ve Keklik 2018: 4). "Ayda beş akçe” hesabına göre yıl boyu işleyen değirmenlerden 60 akçe, altı ay işleyen değirmenlerden 30 akçe ve 3 ay işleyen değirmenlerden ise 15 akçe vergi alındığı anlaşılmaktadır. Fakat burada dikkat edilmesi 
gereken diğer bir husus, alınan vergilerin değirmen hesabı üzerinden değil de değirmende işletilen taş sayısı üzerinden olduğudur. ${ }^{14}$ Buna göre Tosya nahiyesi genelinde bulunan 40 değirmenden yaklaşık 1840 akçe vergi alınmaktadır. Değirmen bulunan köyler arasında en fazla vergi, 280 akçe ile Tosya şehrinden tahsil edilmektedir. Tosya şehrinin ardından sırasıyla 225 akçe ile Harsanid, 180 akçe ile Aluç ve 175 ile Dikmen köyleri gelmektedir. Diğer taraftan en az vergi veren yerleşmeler ise sırasıyla Kayı ve Göbene 15 akçe, Bağözü 30 akçe şeklindedir. Gökçeöz köyünde ise değirmen bulunmasına rağmen "harab" olduğu için herhangi bir vergi alınmamıştır.

\subsection{HARAP DEĞİRMENLER}

Tahrir defterlerinde 1578/1579 tarihinde kayda geçirilen değirmenlerin 9'unun harap olduğu belirtmiştir. Ermenli (1 değirmen), Ulusekü (2 değirmen), Berçin (1 değirmen), Derinköz (1 değirmen), Dikmen (1 değirmen), Kuzyaka (1 değirmen), Karı (1 değirmen), Gökçeöz (1 değirmen) köyleri ilgili tarihte harap değirmenlerinin bulunduğu yerleşmeler olarak karşımıza çıkmaktadır. Arazi araştırmaları sırasında gerçekleştirilen mülakatlar neticesinde değirmenlerin harap olmasına dair bazı ipucu mahiyetindeki bilgiler elde edilmiştir. Bu bağlamda Çepni köyünde yapılan görüşmede ${ }^{15}$, köyde bulunan değirmenin bir kütle hareketi (heyelan), (Şekil 6) neticesinde su yolunun kapandığı ve dolayısıyla artık kullanılamaz hale geldiği belirtilmiştir.

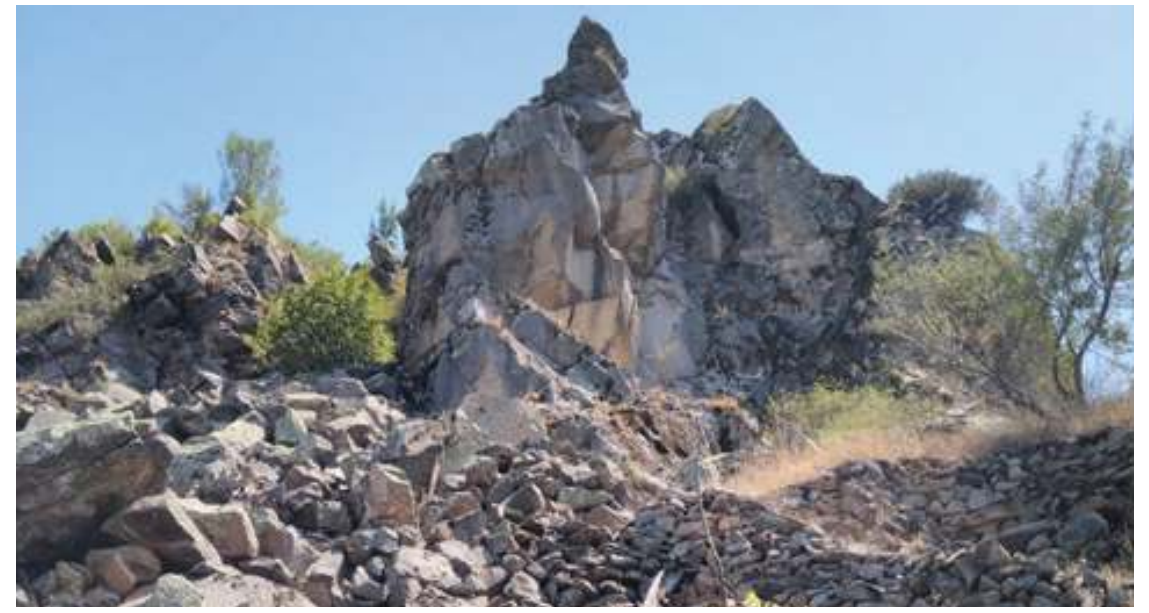

Şekil 6: Değirmenin Harap Olmasına Neden Olan Kütle Hareketi (Çepni Köyü)

\footnotetext{
14 Örnek olarak: 3 değirmen taşı bulunan bir değirmen 7 ay çalıştırılacak olunursa, buradan alınacak vergi: $3 \times 5 \times 7=105$ hesabıyla tahsil edilmiştir.

15 Önceleri ailesinin değirmencilik yaptığını belirten Mustafa adındaki kişiden alınan sözlü ifadedir.
} 
Yine Çepni köyünde bulunan bir başka değirmenin âtıl bırakılmasının sebebi için, akarsuyun öncelere nispetle daha cılız aktığı ve dolayısıyla değirmeni döndürecek kuvvette suyun gelmemesi gerekçe olarak belirtilmiştir. Ermenli köyünde yapılan bir görüşmede ${ }^{16}$ ise zamanla su değirmenlerinin terkedilmesine ilişkin olarak, elektrikle çalışan değirmenlerin ortaya çıkmasından sonra eskisi kadar su değirmenlerinin ilgi görmediği ve dolayısıyla daha kullanışlı olan elektrikli değirmenlere geçildiğini belirtilmiştir. Bunlara ek olarak, aşırı yağışlara bağlı olarak akarsuyun taşkın yapması, yangınlar ve iç siyasi sebepler (Yörük 2014: 642) gibi faktörler değirmenlerin harap hale gelmesine etki eden diğer nedenlerdir. Özetle değirmenler yer şekilleri, hidrografik unsurlar ve klimatolojik faktörler, doğal afetler gibi fiziki coğrafya şartlarının yanı sıra elektrik enerjisini yaygınlaşması, değirmen bulunan yerleşmelerin terk edilmesi ve su tasarruf hakkına dayanan tartışmalardan kaynaklı olarak harap hale geldiği değerlendirilebilir. 


\section{SONUÇ ve DEĞERLENDİRME}

İlkçağdan itibaren insanoğlu buğdayı ezmek için farklı yöntemler kullanmıştır. Buğdayı öğütmek için kullanılan aletlerin en ilkelinden en modernine kadar hepsine değirmen denilmektedir. Ortaya çıktığ ilk günden itibaren değirmenler, insan hayatını kolaylaştıran ve tarımın tamamlayıcısı olarak işlev gören önemli tesisler olmuşlardır. Çeşitli medeniyetler tarafından farklı şekillerde tasarımları yapılmış olan değirmenler; insan ve hayvan, su, rüzgâr, endüstri devrimiyle beraber buhar, elektrik ve petrol gibi farklı enerji kaynaklarıyla işletilmesi sağlanmıştır.

Her sanayi öncesi toplumda olduğu gibi değirmenler, Osmanlı İmparatorluğu için de önemli bir yere sahipti. Zira ekonomik ve sosyal temellerini tarım üzerine oturtan bir imparatorluk için değirmenler hem gelir kalemi, hem de halkın geçimlik un ihtiyacını karşılaması bakımından oldukça önemli olmuştur.

Tosya nahiyesi genelinde 1578/1579 senesinde 49 adet değirmen mevcut olup bu değirmenlerin 40'1 aktif bir şekilde çalışırken 9'u harap olduğu için kullanılmamaktaydı. Söz konusu 49 değirmenin ise toplamda 99 değirmen taş1/işletilen ünitesi olduğu görülmektedir. Buna göre, Tosya nahiyesinde bulunan 3557 hanenin her 89'una 1 değirmen, her 480 kişiye bir değirmen düşmektedir.

Değirmenlerin yerleşmeler açısından dağılışına bakıldığında düzensiz bir dağılım göstermesi, Tosya nahiyesinin kurulmuş olduğu sahanın fiziki coğrafya şartları yakından ilgilidir. Bu duruma en büyük etken iklim koşullarından dolayı yazın akarsuların kuruması ve kışın ise aşırı soğuklardan donması örnek gösterilebilir. Ayrıca Devrez Çayı ile ikiye ayrılan Ilgaz ve Geçmiş Dağları üzerinde en fazla değirmen 27 ile Ilgaz Dağları'nda bulunmaktadır. Geçmiş Dağları'nda bu sayı neredeyse yarı yarıya azalma göstererek 13'e düşmektedir.

Değirmenlerin harap olmasında yerleşmelerin terk edilmesi, yangınlar, sel baskınları, kütle hareketleri ve değirmeni işletecek olan suyun azalması, elektrik enerjisi ile çalışan değirmenlerin ortaya çıkması ve su kullanımı konusundaki anlaşmazlıklar gibi sebepler etkili olmuştur. Bu çerçeveden bakıldığında değirmenlerin kurulmasında, işletilmesinde ve harap olmasında doğal çevre şartlarının yanı sıra beşerî unsurların önemli derecede etkili olduğu değerlendirilmektedir. 


\section{KAYNAKLAR}

Basalla, G. (1988). Teknolojinin Evrimi. (Çev. C. Soydemir,). TÜBİTAK, Ankara.

Bir, A., Acar, M.Ş. ve Kaçar, M. (2012). Anadolu’nun Değirmenleri. YEM Yayınları, İstanbul.

Büyük Larousse Sözlük ve Ansiklopedisi, (1986). C. 6, s. 2940.

Cotterel, B. ve Kammınga, J. (2002). Endüstri Öncesi Teknolojilerin Mekaniği. Literatür Yayınları, İstanbul.

Çınar, H. ve Gümüşçü, O. (2002). Osmanlıdan Cumhuriyete Çubuk Kazası. Çubuk Belediyesi.

Gimpel, J. (1996). Orta Çağ'da Endüstri Devrimi. TÜBİTAK Yayınları, Ankara.

İbret, B. (2003). Tarihi İpek Yolu Üzerindeki Bir Anadolu Şehri Tosya (Kuruluşu ve Gelişmesi). Marmara Coğrafya Dergisi, S. 8, s. 53-82.

İnalcık, H., ve Pamuk, Ş. (Ed.). (2000). Osmanlı Devleti'nde Bilgi ve İstatistik. T.C. Başbakanlık Devlet İstatistik Enstitüsü Yayınları Ankara.

İzgi, Ö., ve Wang, Y.(1989). Çin elçisi Wang Yen-te`nin Uygur Seyahatnamesi. Türk Tarih Kurumu Basımevi, Ankara.

Kankal, A. (2009). XVI. yüzyılda Çankırı. Çankırı Belediyesi Kültür Yayınları, Çankırı.

Keklik, E. ve Keklik, H. (2018). 1579 Tarihli Çankırı Mufassal Tahrir Defteri. Çankırı Belediyesi Kültür Yayınları, Çankırı.

Koç, Ü. (2004). XVI. Yüzy1l Anadolu'sunda Değirmenler. Türk Dünyası Araştırmaları S. 149, 181-190.

Landels, J. G. ve Bıçakçı, B. (2000). Eski Yunan ve Roma'da Mühendislik. TÜBİTAK Yayınları, Anakara.

Öz, M. (1999). XV-XVI. Yüzyıllarda Canik Sancağı. Türk Tarih Kurumu Basımevi, Ankara.

Özaydın, A. (1993). Dânişmendliler. Türkiye Diyanet Vakfi İslam Ansiklopedisi, Türkiye Diyanet Vakfi Yayınları C. 8, s. 469-474.

Pakalın, M.Z. (1993). Osmanlı Tarih Deyimleri ve Terimleri Sözlüğü. Millı̂ Ĕgitim Bakanlığı Yayınları, İstanbul, C. 2, s. 573. 
Seçer, F. (2002). İstanbul'daki Osmanlı Dönemi Değirmenlerinin Mimari Açıdan İncelenmesi ve Unkapanı Değirmeni'nin Günümüz Şartlarında Değerlendirilmesi. MSÜ Fen Bilimleri Enstitüsü (Basılmamış Yüksek Lisans Tezi), İstanbul.

Sezen, T. (2006). Osmanlı Yer Adları. T.C. Başbakanlık Devlet Arşivleri Genel Müdürlüğü, Ankara.

Strabon, (1933). Antik Anadolu Coğrafyas1, Geographia: XII-XIII-XIV, Arkeoloji ve Sanat Yayınları, İstanbul

Tanrıkulu M. (1999). Tosya İlçesinin Ekonomik Coğrafyası. (Basılmamış Yüksek Lisan Tezi), Ankara Üniversitesi, Sosyal Bilimler Enstitüsü (Basılmamış Yüksek Lisans Tezi), Ankara.

Tosun Soyel, N. (2009). Kuzey Kıbrls'taki Tarihi Su Değirmenleri ve Kırsal Peyzajın Parçası Olarak Korunmaları İçin Öneriler. İstanbul Teknik Üniversitesi Fen Bilimleri Enstitüsü (Basılmamış Doktora Tezi), İstanbul.

Yeniçeri, C. (1991). Bâc. Türkiye Diyanet Vakfi İslam Ansiklopedisi, Türkiye Diyanet Vakfı Yayınları, İstanbul, C. 4, 411-413.

Yiğit, A. (2007). XIV-XVI. Yüzyıllarda Menteşe Livasında Değirmenler. Muğla Üniversitesi Sosyal Bilimler Enstitüsü Dergisi, S. 18, s. $97-155$.

Yörük, D. (2014). XVI. Yüzyılda Konya Kazasında Su Değirmenleri ve Bezirhaneler. Turkish Studies-International Periodical For The Languages, Literature and History of Turkish or Turkic, C. 9/1, s. 637-655. 
